Prof. J. D. Bernal, Mr. E. J. Carter, Dr. Arundell Esdaile, Dr. C. H. Desch and Mr. R. A. Lochner. The chairman opened the proceedings with a summary of the relevant parts of the law of copyright. The making of a photographic copy is obviously "reproduction of the original" within the meaning of the Acts, but since the Acts permit "fair dealing" with an original for the purposes of private study and research, the problem raised by photographic reproduction is largely "When is dealing fair ?" In the course of the answers to this question, in which the audience shared freely, Prof. Bernal thought that scientific workers have long been breaking the law not only for study but also for criticism. To him, "fair dealing" implied the question: Was the photocopying service one for which money could reasonably be asked by the owner of the copyright? If the copies were made for the use of one or two persons only, it would be very different from copies made for classteaching on a large scale. Dr. Esdaile amplified this by saying that fair dealing ceased when the commercial interests of the owner were injured. Mr. A. G. Dance, of the Ministry of Education, said that the matter is one of great consequence, and some decision must soon be reached because the Ministry was hoping to see a very considerable increase in the use of film strip after the War. Several speakers urged the advertising value of photocopies. If production of photocopies, so far from reducing the demand for the original, stimulated such a demand (as has happened with the B.B.C. in the concert field), then injury to the owner of the copyright could scarcely be said to have occurred. Mr. Tritton went further, stating that the authors of much of the material now being microfilmed are individual scientific men and other professional workers whose greatest reward lies in the wide dissemination of their works, for which they rarely receive payment in money. Mr. Chilton added that the copying of individual articles in journals puts these articles at the disposal of research workers who only in rare instances could be expected to subscribe to the original journals, especially when account is taken of the widespread scatter of material on any one subject throughout the thousands of current scientific and professional periodicals. It was generally agreed, however, that since publishing bodies are inevitably business concerns, copyright problems cannot be got round in this way.

Dr. R. S. Hutton and Mrs. Moholy pointed the way to a solution of the problem, first referring to present U.S. practice whereby the purchaser of a photocopy declares that he will not use the copy other than for the purpose of private study, and secondly calling for a less cumbersome arrangement with the owners of copyright than the present one, which requires that in cases of doubt the copying agency has to make contact with the owner before proceeding with the copying. Time-saving being one of the greatest advantages of photocopying methods, it is desirable to have an automatic arrangement with copyright owners concerning the terms under which they are prepared to permit photocopying. It would then be possible for a copying agency like ASLIB to carry out its work without specific reference to publisher or author in any particular case.

It has been impossible in the course of a brief review to cover the many interesting points arising from this conference, but it is understood that the proceedings will be available in due course.

L. V. Chilton.

\section{BRITISH MUSEUMS DURING THE WAR YEARS}

"THE great task of museums and art galleries in this country during the War is to help preserve the basic sanity of our peoples and anything that can be done in this respect will be of greater ultimate value than most of us perhaps can now realize." These words are quoted from a message from Major S. F. Markham to members of the Museums Association in 1940. How the museums and art galleries have endeavoured to carry out this task is the subject of the leading article entitled "Endeavour and Achievement", appearing in the Museums Journal of April 1945. The information contained therein is based upon the many museum and art gallery reports received regularly at the offices of the Museums Association in London.

The author states that the large majority of these institutions have not only continued their activities throughout the war period, but also that they have considerably risen in public appreciation ; that their development, far from being curtailed by war conditions, has been greatly accelerated; and that "the support of museum and art gallery activities is now accepted as a normal service in any progressive city or town". Some of the causes leading to this satisfactory position are to be looked for in the popular short-term exhibitions of material supplied by government departments, the Council for the Encouragement of Music and the Arts, and many other organizations ; the co-operation of the museums and art galleries with government departments and the various Services in the provision of instruction for men and women in the Forces, and of loan-exhibits to camps, canteens and clubs; the arrangements made for discussion groups, concerts and art exhibitions; the many informative exhibits and talks dealing with the need for fuel economy, paper salvage, food production and so on ; and the special catering for the needs of leisure and thought by careful presentation of artistic, historical and scientific material.

That the need for such amenities is very real is proved by the overwhelming response of the public wherever they are provided, and the results fully demonstrate that where the service is well rendered, there will it be well received-indeed, even demanded. Nevertheless, the high attainments of even a majority of institutions must not be allowed to mask the fact that there are still far too many areas in Great Britain where the museum service is static, in decay, or even non-existent. Further, reports from even the larger museums continue to stress the need for expansion, better staffing, better working facilities, and more adequate expenditure; and there has been much criticism from not unimportant quarters. Even the writer of the article outlined above is aware of such matters, for he writes, ". . . it is of paramount importance that museums and art galleries should turn their present proud position to good account when peace returns. Directors and curators should take their rightful place in the circle of leading professional men and women who render notable service to the community". And again, "The Museums Association is staking a general claim for the advancement of museums and art galleries throughout the country, but local authorities must adapt this according to their individual needs". At this point, however, one may doubt whether all local authorities 
are sufficiently interested in, or informed of, this particular public service, and hence whether they are qualified to come to any conclusion at all about such 'needs'. One more statement from the article under consideration is worth quoting for the light it throws upon a not uncommon official attitude towards museums : "Museums have been the Cinderellas of the services for too long a time". It is evident, therefore, that many of these institutions are at present in a state of suppression, and that the cause may be ill-informed, ungenerous, or timid rule. It is evident, also, that various authorities, whether they are responsible for the conduct of a museum service or not, have yet to be convinced of the value of the museum in the fields of education and research, and in the intelligent and constructive use of leisure.

\section{HISTORICAL LIBRARY OF YALE UNIVERSITY SCHOOL OF MEDICINE}

$\mathrm{T}$ $\mathrm{HE}$ difficulties of scientific libraries, the meagre funds sometimes allocated to them and the devoted labours of those who work obscurely in them for the benefit of science are often not adequately appreciated by those who would be the first to maintain that libraries are essential tools of research. It would, indeed, do most undergraduates and research workers in science departments no harm to work for a month or two in a library ; for only those who have sufficient imagination can realize, without this practical experience, all the labour and organization which goes to the making of an efficient library service. One record of this kind of service is given in the reports for the years 1941-44 of the Historical Library of Yale University School of Medicine (Sterling Hall of Medicine, New Haven, Connecticut).

During the first year (1941-42) this Library, which was endowed by Harvey Cushing and dedicated on June 15, 1941, made vigorous efforts to build up its collections, especially those relating to the medical history of the War of 1914-18; the Library is also associated with the work of the National Research Council's Subcommittee on Historical Records of the medical history of the present War. The same Council financed the publication of a classified bibliography of aviation medicine prepared by the Yale Historical Medical Library, supplements to which have been requested by the National Research Council's Sub-committee. The problems which occupied this busy year are discussed in these reports. One of the Library's most useful decisions was that books should be available on loan without restriction, and many scholars outside Yale have benefited from this. Another valuable service is the opening of the Library for seven days a week.

The Library's outstanding treasures are the collection bequeathed to it by Harvey Cushing himself and the other one bequeathed by Dr. Arnold Klebs, who died in 1943 in Switzerland, where his books await transportation to Yale. These collections will place Yale in the forefront of libraries concentrating on fifteenth-century literature. To them the Library can add, among its other treasures, the collection of Prof. J. F. Fulton relating largely to the seventeenth century. Prof. Fulton's other devoted services to the management and general policy of the Library as chairman of its Advisory Board are evident throughout these reports. He is also consultant to the Army
Medical Library, the system of classification of which the Yale Library now follows. Another feature of the Library's work has been the lectures and demonstra. tions given each year by Dr. Arturo Castiglioni. The Library has issued the catalogue of Harvey Cushing's collection, which has been considered the finest gift of books by a medical man since William Hunter left his library to the University of Glasgow. Cushing's collection is rich in documents on the anatomy of the Renaissance, the surgery of Tudor England and Vesalius' books. The great historical Library now being formed at Yale is a fine memorial to Cushing, and under the care of Prof. John Fulton and his colleagues it will fare well.

G. LAPAGE.

\section{MARINE ECOLOGY IN SOUTH AFRICA*}

DROF. T. A. STEPHENSON and his assistants have studied intensively the intertidal fauna and flora of South Africa for many years, and the result is a valuable series of ecological memoirs. In Part 1 (1939) of this paper, an account was given of zonation in the intertidal belt surrounding South Africa, to which were added details of the distribution of the Patellidæ. The present part describes the distribution on the South African coasts of the more important intertidal species, and defines the geographical components of the fauna and flora. A third part is to be published later which will include, among other items, a comparison of results with those of other workers.

A very large amount of work is entailed in this survey, and the results are of great interest. Altogether a coast-line of about 1,820 miles has been surveyed and about 1,200 species identified. The most important forms on which attention has been concentrated number 318 (202 animals and 116 algæ).

The intertidal fauna and flora comprise four components - a very large warm-water component supreme in the east but dying down westward; a smaller, but important, cold-water component, paramount westward but diminishing eastwards ; a component centred about the south coast, disappearing to the eastward and westward, and a component con. sisting of species which occur around the entire coast from Durban to Port Nolloth. In addition there appear to be components of more local range centred about different parts of the coast.

Two very large elements are included; one endemic or indigenous to South Africa, the other consisting of species with an East African, Indic or Indo-Pacific range. Apart from these, other elements (Atlantic, sub-antarctic, cosmopolitan, etc.) are represented in relatively small proportions. The number of species rises steadily from west to east.

A comparison of the zonation of these coasts brings out roughly a Littorina zone, recognizable throughout although the species of Littorina change from east to west; a Balanoid zone throughout, everywhere inhabited by Patella granularis as well as by barnacles, but westward the barnacles diminish leaving the Patella dominant; a zone of Patella cochlear throughout the greater part of the coast: but at both the eastern and western ends complica. tions appear due to the diminution of that species

* The Constitution of the Intertidal Fauna and Flora of South Africa. Part 2. By T. A. Stephenson. With Plates XII-XIV and 13 text-figures. Ann. Natal Mus., 10, Part 3 (Dec. 28, 1944). 